\title{
Watershed Management Technique to Control Sediment Yield in Agriculturally Dominated Areas
}

\author{
John W. Nicklow
}

Misgana K. Muleta

\begin{abstract}
Non-point source pollution is recognized internationally as a critical environmental problem. In Illinois, soil erosion from agricultural lands is the major source of such pollution. The erosion process, which has been accelerated by human activity, tends to reduce crop productivity and leads to subsequent problems from deposition on farmlands and in water bodies. Comprehensive watershed management, however, can be used to protect these natural resources. In this study, a discrete time optimal control methodology and computational model are developed for determining land use and management alternatives that minimize sediment yield from agriculturally-dominated watersheds. The solution methodology is based on an interface between a genetic algorithm and the U.S. Department of Agriculture's Soil and Water Assessment Tool. Model analyses are performed on a farm field basis to allow capture of different, local stakeholder perspectives, and crop management alternatives are based on a three-year rotation pattern. The decision support tool is applied to the Big Creek watershed located in the Cache River basin of Southern Illinois. The application demonstrates that the methodology is a valuable tool in advancing comprehensive watershed management. The study represents part of an ongoing research effort to develop an even more comprehensive decision support tool that uses multicriteria evaluation to address social, economic, and hydrologic issues for integrative watershed management.
\end{abstract}

Keywords: Optimization, decision support, watershed management, genetic algorithms.

\section{Introduction and Background}

Surface runoff resulting from rainfall or snowmelt moves over and through soil, collecting and transporting natural and anthropogenic pollutants. These non-point source (NPS) pollutants are ultimately deposited into fresh water bodies including rivers, lakes, wetlands, and underlying groundwater. In the United States, NPS pollutants are the primary source of water quality impairment. Consider that as of 1996, agricultural practices, which are major contributors to NPS pollution, are listed as a source of pollution for 70 percent of the impaired river miles surveyed in the nation (USEPA, 2000a). Likewise, in Illinois NPS pollution is the largest single contributor to waters that fail to meet state and federal water quality goals. Primary NPS constituents for the state are specifically listed as nutrients and siltation resulting from the erosion of agricultural land (ILEPA, 1996). Soil erosion, however, is not only limited to causing offsite effects such as deteriorating fresh water quality. In the long term, it significantly threatens productive capacity of agricultural lands due to the loss of topsoil and valuable nutrients. It seems reasonable that water quality impacts and associated threats to agricultural pro- duction could be effectively controlled by properly managing the activities that are responsible for NPS pollution.

A number of governmental programs have been made available to assist stakeholders in the design, implementation, and financing of watershed management plans to prevent and control NPS pollution. For example, over 40 percent of Section 319 Clean Water Act (CWA) grants were designated for the control of agricultural NPS pollution. Similarly, several U.S. Department of Agriculture and state-funded programs provide cost-shares, technical assistance, and economic incentives such as the Conservation Reserve Program (CRP) to implement NPS pollution reduction practices (USEPA, 2000b). As mandated by the CWA, the United States Environmental Protection Agency (USEPA) recently required states to submit proposed Total Maximum Daily Load (TMDL) criteria after identifying the water bodies and pollutants to which these pollutant load limits would apply. Accordingly, the Illinois Environmental protection Agency (ILEPA) has completed a draft of its 303(d) list, documenting those water bodies in need of TMDL implementation plans. NPS pollution within those water courses identified must be reduced to a level less than TMDL. A viable solution to this pollutant 
reduction problem exists through the alteration of existing or currently planned agricultural land-use patterns.

The effectiveness of land-use decisions aimed at preventing negative impacts from NPS pollution is extremely sensitive to the capability of the water quality and hydrologic model used to predict erosion characteristics that would result from proposed landscape alternatives. Fortunately, over the last three decades, advances in hydrologic science and engineering, as well as computer capabilities, have stimulated the development of a wide variety of mathematical models for such predictions. Some of those models integrate Geographic Information System (GIS) technology, which improves their data management, retrieval, and visualization capabilities. These developments continue to emerge in response to a need to better understand the cause-effect relationships between land use changes and runoff processes, as well as the need to develop tools that can be more easily used by decision makers in evaluating appropriate action plans (Heathcote, 1987; Thomann, 1982). The most comprehensive simulation techniques are process-based, distributed models such as SHE (Abbott et al., 1986), AGNPS (Young et al., 1987), ANSWERS-2000 (Bouraoui and Dillaha, 1996) and Soil and Water Assessment Tool, or SWAT (Arnold et al., 1998), which have replaced traditional lumped, empirical models. Distributed models are able to capture the spatial and temporal heterogeneity of environmental factors such as soil, land use, topography, and climate variables, thus making their resulting estimates more accurate. These types of predictive models by themselves, however, are useful only for evaluating what if scenarios and testing current management alternatives. They are unable to directly solve water resources management and control problems that require decisions to be made.

A comprehensive decision-making framework for watershed management requires the integration of a water quality and hydrologic simulation model and a suitable optimization technique that is capable of solving complex control problems. This integrative method, referred to here as a discrete-time optimal control methodology, has been increasingly popular in water resources related fields and has provided solutions for large-scale problems in areas of reservoir management (Nicklow and Mays, 2000; Unver and Mays, 1990; Yeh, 1985), bioremediation design and groundwater management (Wanakule et al., 1986; Yeh, 1992; Minsker and Shoemaker, 1998), and design and operation of water distribution systems (Cunha and Sousa, 2000; Sakarya and Mays, 2000). Nicklow (2000) provides a comprehensive review of the benefits of the approach, which include a reduced need for additional simplifying assumptions about the problem physics in order to reach an optimal policy and a decrease in size of the overall optimization problem. Furthermore, if the developer is able to incorporate existing simulation procedures that have been widely accepted in engineering practice, the optimal control model attempts to improve the practical utility of the approach. When applied to a typical NPS pollutant reduction problem, the approach allows the direct determination of land-use patterns and tillage practices that solve the following formulation.

- Minimize: sediment yield from a watershed

- Subject to: (1) water quality and hydrologic relationships that govern erosion and sedimentation processes; and (2) crop management constraints, such as crop season and sequence.

There have been minimal applications of this type integrative modeling technique for comprehensive watershed management. Dorn et al. (1995) and Harrell and Ranjithan (1997) used a similar technique to determine the optimal design of storm water detention ponds to achieve sediment removal requirements on a watershed scale. Sengupta et al. (2000) developed a spatial decision support system capable of evaluating the effect of proposed watershed conservation policies by linking the Agricultural Non-Point Source Pollution (AGNPS) model and a linear programming model known as GEOLP. GEOLP is an enhanced version of an economic farm model developed by Kraft and Toolhill (1984) and was used to maximize annual farm income, rather than control NPS pollutants. In this paper, we expand the application of the optimal control methodology for solution to a typical NPS pollution reduction problem. The methodology is designed to directly locate the land use pattern that minimizes sediment yield from a watershed subject to specified constraints. The particular approach used here interfaces the physically-based, distributed hydrologic model known SWAT with an evolutionary optimization technique known as a genetic algorithm (GA). Capabilities of the methodology and resulting integrative model are demonstrated through an application to the Big Creek watershed, a Southern Illinois watershed placed on the 303(d) list by ILEPA as a result of its excessive sediment yield.

\section{Mathematical Formulation}

For the NPS pollutant problem being studied, the vector of decision variables is represented as seasonal cropping and tillage practices that define an agricultural landscape. The important state variable under consideration is sediment yield that occurs in response to the applied land-use pattern. The problem can be expressed mathematically as

$$
\text { Min } Z=\frac{\sum_{\mathrm{t}=1}^{\mathrm{T}} \mathrm{y}_{\mathrm{t}}}{T}
$$


subject to the transition constraint

$$
y_{t}=f\left(C_{s}, T_{s}, X_{s}, t, s\right)
$$

and crop management constraints, expressed in functional form as

$$
g\left(C_{s}, T_{s}, t, s\right) \leq 0
$$

where $Z$ represents the function to be minimized; $y_{t}$ is annual sediment yield; $T$ is the number of years in the simulation horizon; and $C_{s}, T_{s}$ and $X_{s}$ represent crops planted, tillage practices implemented, and all other hydrologic and hydraulic factors that may affect erosion processes, respectively, during season $s$ of year $t$.

Equation 1 is the separable objective function to be minimized and represents the mean annual sediment yield. The function implicitly depends on a particular landscape through the governing dynamics of water quality and hydrologic phenomena. The transition constraint, Equation 2 , represents the laws that govern water quality and hydrologic processes and is used to describe the stage-bystage response of the watershed system according to an imposed land-use pattern. The transition equation for the current problem is comprised of relationships for water and sediment continuity, the universal soil loss equation, and many others. Equation 3 defines a feasible range for decision policies. These policy constraints, together with the transition constraint, define the feasible solution space for the sedimentation problem. Note that the formulation stated here could easily be modified in a number of ways, including the examination of other pollutants, the inclusion of multi-objective criteria, or the addition of alternative policy constraints. The general solution methodology, however, would remain consistent with that presented herein.

\section{Water Quality and Hydrologic Simulation}

The transition constraint provided in the current problem formulation is best solved using a comprehensive watershed simulation model. With respect to the variety of models available, distributed models are better suited to solve watershed management problems than empirical and lumped routing models because of their use of spatially dynamic parameters. The U. S. Department of Agriculture's watershed management model, SWAT, represents a prime example of one such model. SWAT is a continuous-time (e.g., long-term yield) simulator developed to assist water resource managers in routine assessment of water supplies and the effects of NPS pollution in large river basins (Arnold et al., 1998; ASCE, 1999). The model operates on a daily time step and allows a watershed to be subdivided into natural sub-watersheds. Distributed rout- ing of flows occurs on this sub-watershed scale. In addition, each sub-watershed can be further subdivided into a number of Hydrologic Response Units (HRU), defined by a unique combination of land use and soil type heterogeneity. All factors such as soil type, land management practice, and climate are considered homogeneous on a scale of an HRU.

While the model can be used to study more specialized processes such as bacteria transport, the minimum data required for execution are commonly available from government agencies. SWAT input can be divided into the following categories: hydrology, weather, sedimentation, soil temperature, crop growth, nutrients, pesticides, and agricultural management techniques applied. Weather variables that drive the hydrologic model include daily precipitation, maximum and minimum air temperature, solar radiation, wind speed, and relative humidity. For watersheds lacking adequate weather data, a stochastic weather generator can be used for all or several variables and is based on monthly climate statistics that are calculated from long-term measured data from a weather station that is geographically near the watershed. In addition, weather data can be permitted to vary according to specific subwatersheds, depending on data availability.

SWAT is designed to simulate major hydrologic components and their interactions as simply and yet realistically as possible (Arnold and Allen, 1996). Hydrologic processes that are modeled include surface runoff, estimated using the SCS curve number or Green Ampt infiltration equation; percolation, modeled with a layered storage routing technique combined with a crack flow model; lateral subsurface flow; groundwater flow to streams from shallow aquifers; potential evapotranspiration by the Hargreaves, Priestley-Taylor, and PenmanMonteith methods; snow melt; and transmission losses from ponds. For additional detailed information, the reader is referred to Arnold et al. (1998).

Sediment yield is computed for each HRU using the Modified Universal Soil Loss Equation (MUSLE). Whereas the original Universal Soil Loss Equation (USLE) uses rainfall as an indicator of erosive energy, the MUSLE uses the quantity and rate of runoff to simulate erosion and sediment yield. The substitution results in a number of benefits including increased prediction accuracy, elimination of the need for a delivery ratio, and the computation of sediment yield on a single storm basis. The MUSLE can be expressed as

$$
y=11.8 V\left(q_{p}\right)^{p .56} K C P(L S)
$$

where $y$ is the sediment yield from an HRU in tons; $V$ is the surface runoff column for the HRU in $\mathrm{m}^{3} ; q_{p}$ is the peak flow rate for the HRU in $\mathrm{m}^{3} / \mathrm{s} ; K$ is a soil erodibility factor; $C$ is a crop management factor, which accounts for crop rotations, tillage methods, crop residue treatments, and other cultural practice variables; $P$ is an erosion con- 
trol factor, and $L S$ is the slope length and steepness factor (Arnold et al., 1999; Yang, 1996).

A quick observation of the MUSLE reveals a range of possibilities for reducing sediment yield from watersheds. These include the minimization of erosive potential of rainfall using alternative ground covers, the usage of tillage practices that cause less soil disturbance, the reduction of long, steep slopes through construction of terraces and check dams, and the proper choice of land use and management combinations. Land use and tillage practices in particular play a very significant role in reducing erosive power of rainfall by binding the soil and reducing soil mobility and by increasing roughness coefficients to retard transport.

Crop growth is simulated with a daily time step and crop management factor values in the MUSLE are calculated for all days that runoff occurs, thus accounting for stage of crop growth and improving accuracy of model results. Using crop-specific input parameters that are included in the model as a database, one can simulate a variety of annual and perennial crops. Agricultural management practices include tillage techniques, planting and harvesting dates of crops, fertilizer and pesticide types, application dates, and dosages and cropping sequences. The model also provides an estimate of crop yield and accounts for crop yield reduction that may arise due to stresses such as the lack of sufficient precipitation and/or fertilizer. Finally, SWAT operates on an Arcview@ GIS platform which greatly assists in the generation of model input parameters, the execution of simulations, and the visualization of graphical and tabular outputs. These numerous features make SWAT a comprehensive mechanism for assessing both environmental and economic effects of alternative land management practices, and as such, a suitable tool for solving the transition constraint of the current optimization problem.

\section{Genetic Algorithms for Optimal Control}

The overall NPS pollutant control problem is solved using a genetic algorithm (GA). These algorithms are a robust, heuristic search procedure that relies on stochastic search rules. Developed by Holland (1975), these algorithms represent an attempt to adapt the mechanisms of natural selection to problems in which traditional, deterministic search techniques typically fail. Although there is no rigorous definition that applies to all GAs, they are characterized by the following common elements: (1) generation of an initial population of potential solutions, each identified as a chromosome; (2) computation of the objective function value, or fitness metric, of each solution and subsequent ranking of chromosomes according to this metric; (3) selection of the fittest solutions to undergo crossover; (4) random selection of mating pairs of solutions; (5) performance of a crossover operation in which information describing decision variables, or genes, from two par- ent solutions are combined to create offspring solutions; and (6) mutation of a portion of the new offspring to maintain diversity (Mitchell, 1996; Haupt and Haupt, 1998). These elements are repeated in subsequent generations until a suitable solution is obtained. The general concept behind these elements is that solutions having high fitness values contain specific genes that are important to optimizing the objective function. By exchanging important genes between two parent alternatives, it is expected that the GA will produce some offspring that contain even more superior characteristics than their parent alternatives. In this way, GAs simulate survival and generation-based propagation of those solutions that have the best objective function values (Belegundu and Chandrupatla, 1999). In addition, GAs tend to be an aggressive search technique that may potentially converge to local optima. To discourage this tendency and to maintain a wide-search of the solution space, genes within any given generation are randomly mutated.

GAs are quite different from traditional gradient-based optimization techniques in that they require no derivative information about the objective function or constraints. Instead, the objective function magnitude, rather than derivative terms, is used to display incrementally better solutions, making GAs amenable for application to nonconvex, highly nonlinear and complex problems (Goldberg, 1989). As a result, the method has proven to be a valuable tool for solving a broad spectrum of optimization and control problems in water resources engineering and management (Esat and Hall, 1994; Hellman and Nicklow, 2000; Hilton and Culver, 2000; McKinney and Lin, 1994; Nishikawa, 1998; Oliveira and Loucks, 1997; Reis et al., 1997; Ritzel et al., 1994; Savic and Walters, 1997; Wang, 1991; Wardlaw and Sharif, 1999). For a discussion of the detailed framework of genetic algorithms, the reader is also referred to Goldberg (1989), Haupt and Haupt (1998), and Mitchell (1996).

It should be noted that although GAs can be useful for solving a range of complex, nonlinear optimization problems, several disadvantages are inherent in their use. The algorithms can be computationally intensive, particularly in cases where significant computational time and effort is required for objective function evaluation (Hilton and Culver, 2000). The structure of the GA, however, is highly suited to parallel computing, if available. Furthermore, even though GAs search a wide portion of the solution space, they are a heuristic search technique and a globally optimal solution is not ultimately guaranteed (Cieniawski et al., 1995). This is a common characteristic of most nonlinear optimization methods applied to nonconvex systems. However, reliability in locating global optima can be investigated and possibly improved through repeated sensitivity applications of the GA in which the user varies parameters such as solution population size and mutation frequency. In fact, the majority of GA literature consistently demonstrates an ability to identify global or very near glo- 
bal optima for a range of complicated problems (Nicklow, 2000).

\section{Solution Approach}

The optimal control methodology established to solve the NPS pollutant reduction problem relies on an interface between SWAT and a GA, as illustrated in Figure 1. The GA applied in this study was developed exclusively for this research. Decision variables, or genes, are cropping and tillage practice combinations for a particular HRU, which are permitted to change over subsequent seasons. A set of decision variables, or chromosome, that defines a particular landscape then represents a potential solution to the posed problem.

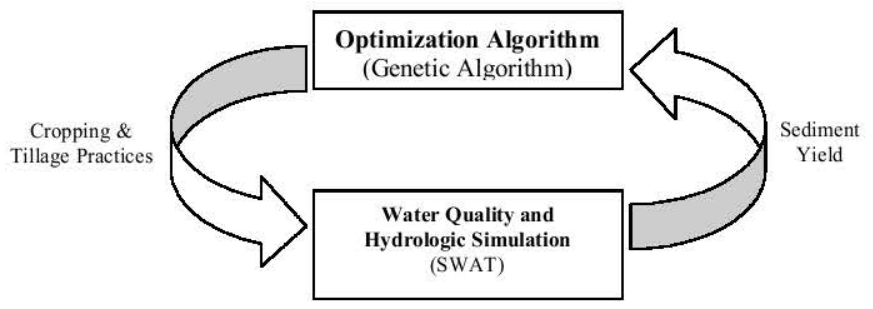

Figure 1. Optimal control solution framework.

The solution methodology assumes that each HRU represents a particular farm field that is singularly or commonly owned by a landowner. Under this assumption, a landowner's decision concerning land uses and tillage types will have no influence on the decisions made by neighboring landowners. Expressed differently, the methodology allows each landowner within the watershed to make independent decisions, but contributes towards the overall goal of minimizing sediment yield to a receiving water body. This approach supports ILEPA's recognition that watershed planning and management begins with the responsibility of farmers and other landowners who have ownership rights within the watershed. Their land use choices directly affect their personal income and affect their shared responsibility to maintain environmental quality. Effective decision making in such cases should thus recognize different stakeholder perspectives.

Farm management decisions are not typically based on single-year concerns, but rather consider multi-year criteria such as crop rotation. It is assumed that a farm management policy dictates the seasonal sequence of crops to be grown on an individual farm field for a three-year time horizon. In the decision process, only field crops are considered and a maximum of two crops per year are permitted to grow. The second crop of the year can be planted only after the preceding crop is harvested. Planting and harvesting dates of crops are assumed to be consistent within the dates recommended for specific crops in the watershed of study, and a crop year is assumed to commence in January. Within a three-year rotation, a maxi- mum of five crops can be grown. The first crop planted in the three-year period is a warm season crop and is harvested in late September. A winter crop is then planted in early October and is harvested in June. Next, using a double cropping system, warm season crops, such as soybean, that can grow following harvest of winter crops are planted. The fourth crop is a warm season crop that is planted in March or April, and finally the fifth and the last crop of the sequence is a winter crop. In addition, once planted, perennial crops such as hay and pasture are allowed to remain on the field until the end of the three-year plan. These criteria represent crop management constraints, which were expressed generally through Equation 3.

The solution begins with hundreds of randomly generated chromosomes, each consisting of five genes, which represent the sequence of land covers and tillage practices to be implemented over a three-year period. The GA code checks for satisfaction of the management constraints during initial choice of alternatives, crossover and mutation operations using systematically assigned crop codes for the various season crops. For example, codes from 1 to 14 were given to warm season crops and genes corresponding to warm seasons were not permitted to assume values outside this range. By design, each chromosome is feasible according to specified crop management constraints. Table 1 provides examples of genes and their assigned integer codes for 8 of the 25 land covers used. Furthermore, Table 2 lists two examples of potential chromosomes. Considering the second alternative in Table 2, sorghum with conventional tillage which is a warm season crop is chosen as gene 1; then wheat with fall tillage is a winter crop chosen as gene 2 ; soybean with no tillage which can be grown over the summer after harvesting wheat is the third land cover; and the last land cover selected over the decision time horizon is pasture with no tillage. Whereas in alternative 1 , silage with spring tillage was proposed as the first gene and the second gene was chosen to be a perennial land cover, which is alfalfa with no tillage. The third, fourth, and fifth genes of the chromosome were then automatically assigned the same land cover (i.e., alfalfa with no tillage) to satisfy the management constraints due to perennial cropping. The water quality and hydrologic simulator is then used to implicitly solve the transition constraint (Equation 2) for each chromosome when the GA

Table 1. Typical Genese Defining Crop Types and Tillage Practices

\begin{tabular}{lllc}
\hline Crop & Tillage Practice & Acronym & Integer Code \\
\hline Soybean & No tillage & SYNT & 1 \\
Corn & No tillage & CRNT & 4 \\
Sorghum & Conventional tillage & SGCT & 8 \\
Wheat & Fall tillage & WWFT & 21 \\
Wheat & No tillage & WWNT & 20 \\
Silage & Spring tillage & SLST & 11 \\
Alfalfa & No tillage & AFNT & 15 \\
Pasture & No tillage & PSNT & 17 \\
\hline
\end{tabular}


Table 2. Typical Management Alternatives

\begin{tabular}{|c|c|c|c|c|c|}
\hline $\begin{array}{l}\text { Chromo- } \\
\text { some }\end{array}$ & $\begin{array}{l}\text { Crop } 1 \\
\text { Warm } \\
\text { Season }\end{array}$ & $\begin{array}{l}\text { Crop } 2 \\
\text { Winter } \\
\text { Crop }\end{array}$ & $\begin{array}{l}\text { Crop } 3 \\
\text { Warm or } \\
\text { Perennial } \\
\text { Crop }\end{array}$ & $\begin{array}{l}\text { Crop } 4 \\
\text { Warm or } \\
\text { Perennial } \\
\text { Season }\end{array}$ & $\begin{array}{l}\text { Crop } 5 \\
\text { Winter or } \\
\text { Perennial } \\
\text { Season }\end{array}$ \\
\hline 1 & $\begin{array}{c}11 \\
(\mathrm{SLST})\end{array}$ & $\begin{array}{c}20 \\
(\mathrm{WWNT})\end{array}$ & $\begin{array}{c}15 \\
(\mathrm{AFNT})\end{array}$ & $\begin{array}{c}15 \\
(\mathrm{AFNT})\end{array}$ & $\begin{array}{c}15 \\
(\mathrm{AFNT})\end{array}$ \\
\hline 2 & $\begin{array}{c}8 \\
(\mathrm{SGCT})\end{array}$ & $\begin{array}{c}21 \\
(\mathrm{WWFT})\end{array}$ & $\begin{array}{c}1 \\
\text { (SYNT) }\end{array}$ & $\begin{array}{c}4 \\
\text { (CRNT) }\end{array}$ & $\begin{array}{c}17 \\
\text { (PSNT) }\end{array}$ \\
\hline
\end{tabular}

requires its solution. The objective function value returned from SWAT represents a three-year average annual sediment yield that occurs in response to implementation of a particular alternative for an HRU. This value establishes the basis for ranking and tournament selection of the fittest pairs of chromosomes that are mated during a random, uniform crossover scheme. Before progressing to the next generation of the GA, genes are mutated according to a user-specified frequency. This cyclic process is continued for a user-defined number of generations, and then repeats for the next defined HRU. The ultimate result is the evolution of land-use patterns that are better suited to solve the NPS pollutant control problem than the individuals from which they were created.

\section{Application to the Big Creek Watershed}

The Cache River basin, shown in Figure 2, is located in Southern Illinois near the confluence of the Mississippi and Ohio Rivers. In 1995, a locally led watershed planning committee established a resource plan for the protection of this basin (CRRPC, 1995). Threats to the basin include the loss and fragmentation of natural habitats, significant changes to the natural hydrologic regimes, and excessive upland erosion and sedimentation (Sengupta et al., 2000.) The Big Creek watershed comprises part of the larger Cache River basin, and is undergoing extensive study as part of the Illinois' Pilot Watershed Program, through cooperation among the Illinois Department of Natural Resources (IDNR), the Illinois Department of Agriculture, ILEPA, and the U.S. Natural Resources Conservation Service (IDNR, 1998). Specifically, this $130 \mathrm{~km}^{2}$ watershed has been cited by the ILEPA for excessive sediment and nutrient loading and is likely to be targeted by pollutant reduction criteria.

A 30-meter resolution U. S. Geological Survey (USGS) Digital Elevation Model (DEM), an IDNR land use map, and a soils map were obtained for the region of study. The land use map had been generated from LandSat imagery collected between April 1991 and May 1995. The Big Creek watershed was delineated from the DEM using the GIS extension of SWAT and was subsequently divided into 128 subbasins that varied in size between $0.29 \mathrm{~km}^{2}$ and 4 $\mathrm{km}^{2}$. The land use map and soils map were then superim-

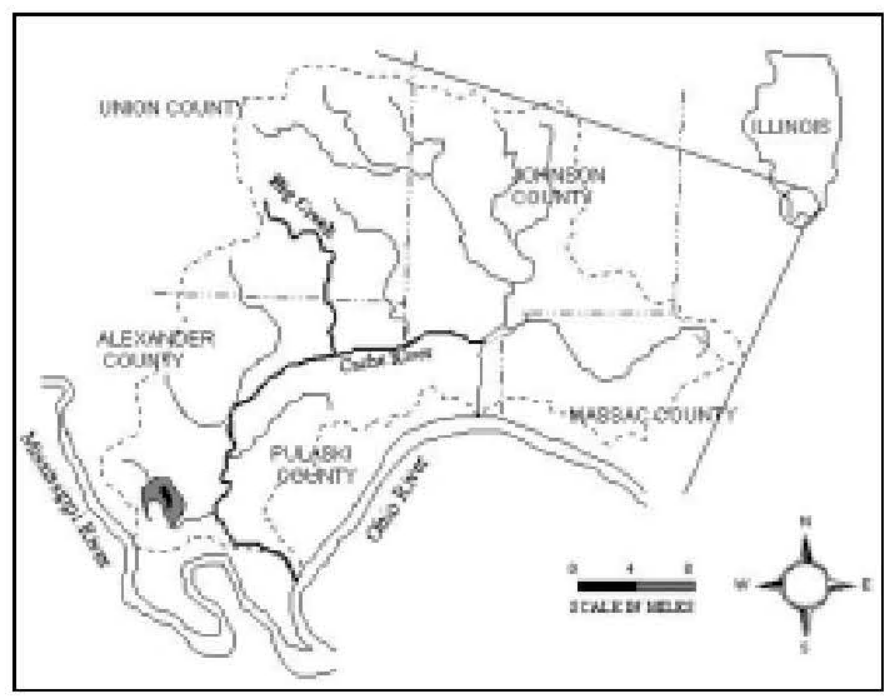

Figure 2. Location of Big Creek and Cache River, Illinois (after Sengupta et al., 2000).

posed over the subdivided watershed to identify HRUs. Historical data related to daily precipitation, daily maximum and minimum temperatures were obtained from the National Weather Service for Anna, Illinois, a nearby weather station. Finally, a database of 25 suitable cropping and tillage practice combinations was prepared for the Big Creek watershed. This database contains additional information on planting dates, harvesting dates, dates to apply tillage, fertilizer and pesticide types, application dates and dosages, and heat units required for a plant to reach maturity.

For this application, dominant soils types and land uses from each subbasin were used in establishing HRUs, a statement that implies that each farm field consists of a single soil type and land cover during any one season. In addition, HRUs that were predominantly classified as a forest, a watercourse, or an urban developed area was not permitted to be converted to agricultural lands and would remain unchanged. It should further be noted that no calibration was performed since sufficient calibration data does not exist at this time. This data is currently being collected, thus permitting extensive calibration efforts in the near future. Nevertheless, application of the model and presentation of results at this stage will allow demonstration of the unique tools developed in this research, as well as their capabilities.

The optimal control model was applied using inputs collected for Big Creek watershed and executed for an initial chromosome population of 500, an upper limit of 50 generations and a mutation rate of 15 percent. For a single HRU, the search took an average CPU time of approximately 4 hours on a $650 \mathrm{Mhz}$, Pentuim III PC for 50 generations. As a consequence to $\mathrm{CPU}$ time and based on initial testing, a maximum of 50 generations was adopted for all HRU's. However, it should be noticed that a 3-year policy is designed for the field during this $4 \mathrm{hr} \mathrm{CPU}$ time. 
The model sequentially located an optimal solution for each HRU defined for the watershed and subsequently identified the optimal basin-wide sediment yield to be $1.2 \times 10^{6}$ metric tons/year. For those HRUs designated as croplands, this three-year average yield corresponds to a 13.4 percent reduction from that given by the early-1990 landscape. To demonstrate solution convergence, search results for one particular 55.71-ha HRU are presented in the plot shown in Figure 3. For this HRU, the sediment yield associated with the best chromosome among the 500 alterna-

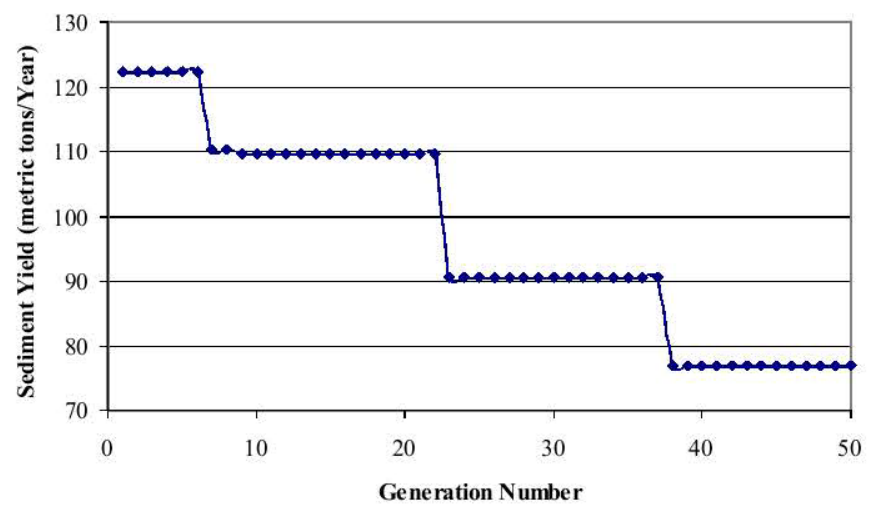

Figure 3. Convergence characteristics for typical HRU.

tives included in a randomly generated population is 121.132 metric tons/year (2.174 metric tons/ha/year), while the average sediment yield from these 500 initial decision alternatives was 268.911 metric tons/year. This minimum yield value is significantly reduced to 76.766 metric tons/ year (1.378 metric tons/ha/year) at the 50th generation.

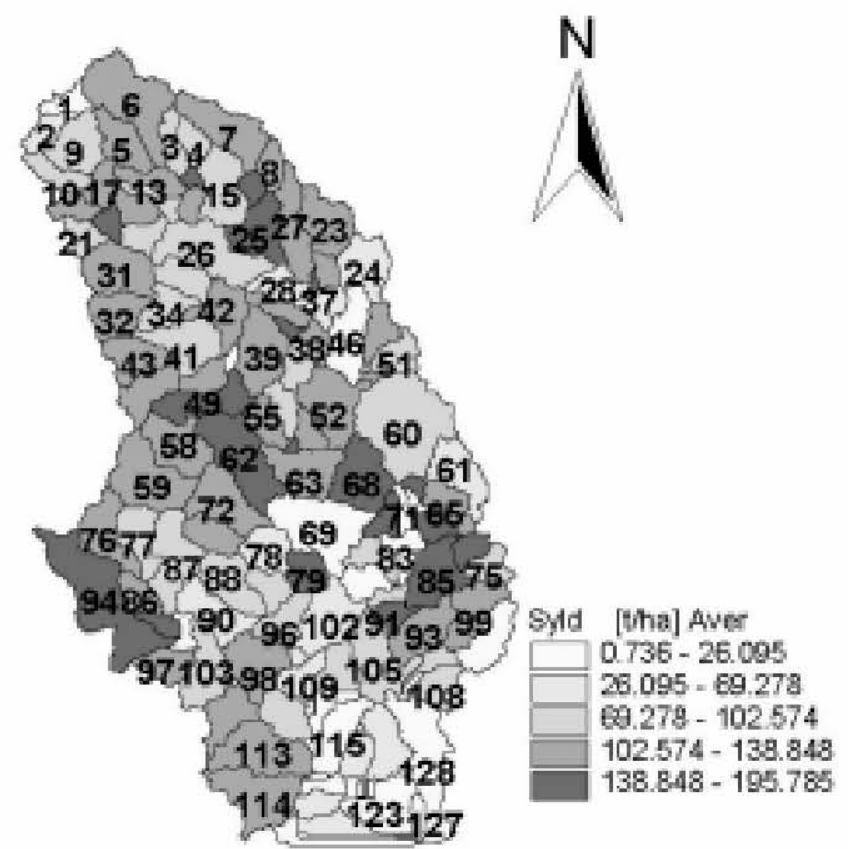

Figure 4. Distribution of sediment yield from Optimal Land Use Pattern.
Spatially distributed sediment yields values that are associated with the derived optimal land use pattern are illustrated in Figure 4.

\section{Conclusion}

A new methodology and computational model have been developed for the direct determination of optimal land use patterns. The overall approach is based upon the coupling of a water quality and hydrologic simulation model and a GA. Its application of the Big Creek watershed has demonstrated a unique capability to minimize sediment yield resulting from upland erosion. The example further reveals the versatility of the optimal control methodology as a comprehensive decision-making mechanism in handling complex, nonlinear control problems such as watershed management.

The formulation and solution techniques applied here can be conducted at the farm field level, thus attempting to integrate varying perspectives of stakeholders and policy makers in developing watershed management and planning decisions. This will likely enhance the validity and trust of the results by local landowners in the watershed of interest. However, to fully capture stakeholder interests, the problem must be expanded to include socio-economic issues. As such, the next phase of this research will be to integrate a multi-objective formulation that also considers economic impact of land use decisions on a farm field basis. The model could be expanded to include objectives related to other NPS pollutants. In addition, reliability of the model under uncertainty from inputs will be addressed in future work. The resulting methodology and computational model will be a comprehensive watershed decision support tool that may potentially play a significant role in meeting water quality criteria such as TMDLs.

\section{Acknowledgements}

The authors wish to thank the Illinois Council for Food and Agricultural Research (CFAR), which has graciously provided support for this ongoing research effort. The writers would also like to acknowledge the efforts of the anonymous reviewers of the paper. 


\section{References}

Abbott, M.B, J.C. Bathurst, J.A. Cunge, P.E. O'Connell, and J. Rasmussen. 1986. "An Introduction to the European Hydrological System - System Hydrologique Europeen, 'SHE,' 2: Structure of a Physically-based, Distributed Modeling System." Journal of Hydrology 87: 61-77.

Arnold, J.G., R. Srinivasan, R.S. Muttah, and J.R. Williams. 1998. "Large Area Hydrologic Modeling and Assessment Part I: Model Development." Journal of the American Water Resources Association 34, No. 1:73-89.

Arnold, J.G., J.R. Williams, R. Srinivasan, and K.W. King. 1999. SWAT: Soil and Water Assessment Tool. Temple, Texas, USA: USDA, Agricultural Research Service.

Arnold, J.G and P.M. Allen. 1996. "Estimating Hydrologic Budgets for Three Illinois Watersheds." Journal of Hydrology 176: 55-77.

ASCE. .1999. GIS Modules and Distributed Models of Watersheds. Reston, Virginia, USA: American Society of Civil Engineers.

Belegundu, A.D. and T.R. Chandrupatla. 1999. Optimization Concepts and Applications in Engineering. Upper Saddle River, New Jersey, USA: Prentice Hall.

Bouraoui F. and T.A. Dillaha. 1996. "ANSWERS-2000: Runoff and Sediment Transport Model." Journal of Environ. Engineering 122, No. 6: 493-502.

Cieniawski, S.E., J.W. Eheart, and S. Ranjithan. 1995. "Using Genetic Algorithms to Solve a Multiobjective Groundwater Monitoring Problem." Water Resources Research 31, No. 2: 399-409.

CRRPC. 1995. Resource Plan for the Cache River Watershed: Union, Johnson, Massac, Alexander, and Pulaski Counties. Ullin, Illinois, USA: Cache River Resource Planning Committee.

Cunha, M.C. and J. Sousa. 2000. "Water Distribution Network Design Optimization: Simulated Annealing Approach.” Journal of Water Resources Planning and Management 125, No. 4: 215-221.

Dorn, J., S.R. Ranjithan, S. Liehr, and R.C. Borden. 1995. “Ge- netic Algorithm Approach to Water Supply Watershed Management." Proceedings of the Conference on Computing in Civil Engineering, ASCE. New York, New York, USA, June 5-8.

Esat, V. and M.J. Hall. 1994. "Water Resources System Optimisation Using Genetic Algorithms." Hydroinfomatics 1994, Proceedings $1^{\text {st }}$ International Conference on Hydroinformatics. Balkema, Rotterdam, The Netherlands.

Goldberg, D.E. 1989. Genetic Algorithms in Search, Optimization and Machine Learning. Reading, Massachusetts, USA: Addison-Wesley.

Harrell, L.J. and S.R. Ranjithan. 1997. "Generating Efficient Watershed Management Strategies Using a Genetic Algorithmbased Method." Proceedings of the 24th Annual Conference of the Water Resources Planning and Management Division, ASCE. Houston, Texas, USA, April 6-9.

Haupt R.L. and S.E. Haupt. 1998. Practical Genetic Algorithms. New York, New York, USA: John Wiley \& Sons, Inc.

Heathcote, I.W. 1987. "Background Review." Pollution Control Planning. W. James, ed. Toronto, Ontario, Canada: Ontario Ministry of the Environment.

Hellman, A. P. and J.W. Nicklow. 2000. "Optimizing Hydraulic Design of Highway Drainage Systems." Proceedings of the 2000 Joint Conference on Water Resources Engineering and Water Resources Planning and Management, ASCE. Minneapolis, Minnesota, USA, July 30-August 2.

Hilton, A.B. and T.B. Culver. 2000. "Constraint Handling for Genetic Algorithms in Optimal Remediation Design." Journal of Water Resources Planning and Management 126, No. 3: $128-137$.

Holland, J.H. 1975 Adaptation in Natural and Artificial Systems. Ann Arbor, Michigan, USA: University of Michigan Press.

IDNR. 1998. The Pilot Watershed Program: Watershed Management, Monitoring and Assessment. Springfield, Illinois, USA: Illinois Department of Natural Resources.

ILEPA. 1996. The Condition of Illinois Water Resources, 19721996. Illinois Environmental Protection Agency. Available Online: $<$ http://www.epa.state.il.us/water/water-quality/condition-of-water-resources.html>.

Kraft, S.E. and T. Toolhill. 1984. "Soil Degradation and Land Use Changes: Agro-ecological Data Acquired Through Representative Farm and Linear Programming Analysis." Journal of Soil and Water Conservation 40: 65-67.

McKinney, D.C. and M.D. Lin. 1994. "Genetic Algorithm Solution of Groundwater Management Models." Water Resources Research 30, No. 6: 1897-1906.

Minsker, B.S. and C.A. Shoemaker. 1998. "Dynamic Optimal Control of In-situ Bioremediation of Groundwater." Journal of Water Resources Planning and Management 124, No. 3:149-161.

Mitchell, M. 1996. An Introduction to Genetic Algorithms. Cambridge, Massachusetts, USA: The MIT Press.

Nicklow, J.W. 2000. "Discrete-time Optimal Control for Water Resources Engineering and Management." Water International 25, No. 1: 89-95. 
Nicklow, J.W. and L.W. Mays. 2000. “Optimization of Multiple Reservoir Networks for Sedimentation Control." Journal of Hydraulic Engineering 126, No. 4: 232-242.

Nishikawa, T. 1998. "Water Resources Optimization Model for Santa Barbara, California.” Journal of Water Resources Planning and Management 124, No. 5: 252-263.

Oliveira, R. and D.P. Loucks. 1997. "Operating Rules for Multireservoir Systems.” Water Resources Research 33, No. 4: 839-852.

Reis, L.F.R., R.M. Porto, and F.H. Chaudhry.1997. “Optimal Location of Control Valves in Pipe Networks by Genetic Algorithm." Journal of Water Resources Planning and Management 123, No. 6:317-320.

Ritzel, B.J., J.W. Eheart, and S. Ranjithan. 1994. "Using Genetic Algorithms to Solve a Multiple Objective Groundwater Pollution Problem." Water Resources Research 30, No. 5: 1589 1603.

Sakarya, A.B. and L.W. Mays.2000). "Optimal Operation of Water Distribution Pumps Considering Water Quality." Journal of Water Resources Planning and Management 126, No. 4: $210-220$.

Savic, D.A. and G.A. Walters. 1997. "Genetic Algorithms for Least-cost Design of Water Distribution Networks." Journal of Water Resources Planning and Management 123, No. 2: 67-77.

Sengupta, R., D.A. Bennett, J. Beaulieu, and S.E. Kraft. 2000. "Evaluating the Impact of Policy-induced Land Use Management Practices on Non-point Source Pollution Using a Spatial Decision Support System." Water International 25, No. 3: 437-445.

Thomann, R.V. 1982. "Verification of Water Quality Models." Journal of Environ. Engineering, 108, No. 5: 923-940.
Unver, O.I. and L.W. Mays.1990. "Model for Real-time Optimal Flood Control Operation of a Reservoir System." Water Resources Management 4: 21-46.

USEPA. 2000a. Managing Non-point Source Pollution from Agriculture. U.S. Environmental Protection Agency. Available Online: <http://www.epa.gov/OWOW/NPS/facts/ point6.htm>.

USEPA. 2000b. National Management Measures to Control Non-Point Source Pollution from Agriculture. Raleight, North Carolina, USA: U.S. Environmental Protection Agency.

Wanakule, N., L.W. Mays, and L.S. Lasdon. 1986. "Optimal Management of Large-scale Aquifers: Methogology and Application." Water Resources Research 22, No. 4: 447-465.

Wang, Q.J. 1991. "The Genetic Algorithm and its Application to Calibration Conceptual Rainfall-runoff Models. Water Resources Research 27, No. 9: 2467-2471.

Wardlaw, R. and M. Sharif. 1999. "Evaluation of Genetic Algorithms for Optimal Reservoir System Operation. "Journal of Water Resources Planning and Management 125, No. 1:2533.

Yang, C.T. 1996. Sediment Transport Theory and Practice. New York, New York, USA: McGraw-Hill.

Yeh, W. W-G. 1985. "Reservoir Management and Operations Models: A State-of-the-art Review." Water Resources Research 21, No. 12: 1797-1818.

Yeh, W.W-G. 1992. "Systems Analysis in Groundwater Planning and Management." Journal of Water Resources Planning and Management 118, No. 3: 224-237.

Young, R.A., C.A. Onstad, D.D. Bosch, and W.P. Anderson. 1987. “AGNPS: A Non-point Source Pollution Model for Evaluating Agricultural Watersheds." Journal of Soil and Water Conservation, 44, No. 2: 168-173. 